\title{
Comparing plastic syringes and disposable columns to extract n-alkanes in forage and concentrate feeds
}

\author{
Comparação de seringas plásticas e colunas descartáveis para extração de n-alcanos em forragens e \\ concentrados
}

\author{
Dimas Estrasulas de Oliveira ${ }^{\mathrm{I}}$ Luis Orlindo Tedeschi ${ }^{\mathrm{I}}$
}

\section{- NOTE -}

\section{ABSTRACT}

Saturated aliphatic hydrocarbons (n-alkanes) were extracted from feed, orts, and bovine fecal samples using disposable, plastic $5 \mathrm{~mL}$-syringes as an alternative material to disposable columns, which are normally used in the liquid-solid extraction phase of n-alkanes. For both methods, the n-alkane extracts (carbon chain length between 31 and 36 atoms) were identified using gas chromatography. The linear regression between methods were: 1$)$ feces: column Alkane $=2.63+0.92 \times$ syringeAlkane $\left[r^{2}=0.94\right.$, square root of the mean square error (RMSE) $=13.7 \mathrm{mg}$ $\left.\mathrm{kg}^{-1}, \mathrm{n}=30\right]$ from which the intercept and the slope did not simultaneously differ from zero and unity $(P>0.05)$, respectively; 2) feeds: column Alkane=0.36+1.12 $\times$ syringeAlkane $\left(r^{2}=0.85\right.$, $R M S E=1.9 \mathrm{mg} \mathrm{kg}^{-1}, \mathrm{n=21}$ ) from which the intercept and the slope did not simultaneously differ from zero and unity $(P>0.05)$, respectively; 3) orts: column Alkane $=0.49+0.92 \times$ syringeAlkane $\left(r^{2}=0.98, R M S E=1.2 \mathrm{mg} \mathrm{kg}^{-1}, \mathrm{n}=15\right)$ from which the intercept and the slope did not simultaneously differ from zero and unity $(P>0.05)$, respectively. Materials with low concentration of $n-$ alkanes may affect the values obtained in both methods. These results suggested that disposable plastic syringes might be a viable alternative to columns thus, reducing analytical costs.

Key words: analysis, digestibility, intake, hydrocarbons, nalkane determination

\section{RESUMO}

$N$-alcanos foram extraídos de alimentos, sobras $e$ fezes de bovinos com a utilização de seringas plásticas descartáveis de $5 \mathrm{~mL}$ como um material alternativo às colunas descartáveis que são normalmente utilizadas para a fase de extração líquido-sólido. Para ambos os métodos, os n-alcanos (cadeias de carbono entre 31 e 36 átomos) foram identificados usando cromatografia gasosa. As regressões lineares entre métodos foram: 1) fezes: coluna Alcano $=2,63+0,92 \times$ seringa Alcano $\left[r^{2}=0,94\right.$, raiz do quadrado médio do erro (RMSE) $=13,7 \mathrm{mg} \mathrm{kg}^{-1}$, $n=30]$, em que o intercepto e o coeficiente angular não diferiram simultaneamente de zero e um $(P>0,05)$, respectivamente; 2$)$ alimentos: coluna Alcano $=0,36+1,12 \times$ seringa Alcano $\left(r^{2}=0,85\right.$, $R M S E=1,9 \mathrm{mg} \mathrm{kg}^{-1}, \mathrm{n}=21$ ), em que o intercepto e o coeficiente angular não diferiram simultaneamente de zero e um $(P>0,05)$, respectivamente; 3) sobras: coluna Alcano $=0,49+0,92 \times$ seringa Alcano $\left(r^{2}=0,98, R M S E=1,2 \mathrm{mg} \mathrm{kg}^{-1}, n=15\right)$, em que o intercepto e o coeficiente angular não diferiram simultaneamente de zero $e$ um $(P>0,05)$, respectivamente. Materiais com baixas concentrações de alcanos podem afetar os valores obtidos em ambos os métodos de extração. Esses resultados sugerem que as seringas plásticas descartáveis podem ser uma alternativa viável às colunas, reduzindo o custo analítico.

Palavras-chave: análise, determinação de n-alcanos, digestibilidade, consumo, hidrocarbonetos.

Aliphatic saturated hydrocarbons (nalkanes) can be used as internal and external markers in nutrition studies with herbivore mammals. However, n-alkanes extraction may not be used as a routine technique in laboratorial feed analysis because time and cost might constraint its practical application. Several research papers have proposed changes in the extraction and analysis procedures, including reduction of the time spent during the process of direct saponification and change of the type of solvent used (DILLON \& STAKELLUM, 1990; VULICH, 1994; VULICH et al., 1995; OLIVÁN \& OSORO, 1999). However, only few papers have evaluated alternative

'Programa de Pós-graduação em Ciência Animal, Universidade do Estado de Santa Catarina (UDESC), 88502-970, Lages, SC, Brasil. E-mail: deolivei2@terra.com.br. Autor para correspondência.

IIDepartment of Animal Science, Texas A\&M University, College Station, TX 77843-2471. USA. 
materials to potentially reduce costs without affecting the analysis. Cost is an important issue with laboratorial chemical analyses in developing countries.

The objective of this study was to compare plastic syringes with disposable columns, which are commonly used to support the silica-gel in the liquidsolid phase of extraction of n-alkanes analysis in forages and concentrate feeds.

Thirty-three samples of individual feeds (corn silage, three different concentrate mixtures composed by ground corn, ground sorghum, corn gluten feed, soybean meal, cottonseed meal, urea, soybean hulls, mineral mix), orts (corn silage plus concentrate) and feces of six steers, from a digestibility trial, dosed with controlled-release n-alkanes capsules containing $8 \mathrm{~g}$ of $\mathrm{C}_{32}$ (n-dotriacontane) plus $8 \mathrm{~g}$ of $\mathrm{C}_{36}$ (n-hexatriacontane) were used for testing alternative methods of extracting n-alkanes. The n-alkane concentrations in silage, concentrate, orts and fecal samples were determined in duplicate using the methodology described by DILLON \& STAKELUM (1990) and modified by OLIVEIRA (2004). Briefly: a) nheptane was used as solvent; b) during the saponification procedure, a bath-water was used instead of a dry-block heater. Extraction was made in duplicates, with changes made only during the liquidsolid phase of the process. These included the replacement of empty columns (Alltech $n^{\circ} 17312$ ) by $5 \mathrm{~mL}$, empty plastic syringes. To support the silica-gel (2.6g) in the syringes, cotton previously washed with petroleum ether during 24 hours in a Soxhlet extractor was used. Loss of solvent before fitting samples in the syringes was avoided by using cut disposable needles with tips sealed with epoxy resin. After rinsing the nalkanes fraction, identification and quantification of $n$ alkanes was made using the $\mathrm{C}_{34}$ as an internal standard through chromatographic analysis following procedure described by OLIVEIRA et al. (2008).

Data for $\mathrm{C}_{31}, \mathrm{C}_{32}, \mathrm{C}_{33}, \mathrm{C}_{35}$ and $\mathrm{C}_{36}$ n-alkanes ( $\mathrm{mg} \mathrm{kg}^{-1}$ of dry matter), for each comparison between syringe and column extract method for feeds, feces, and orts, duplicates were performed and the average was used in the regression analyses for each material. In this study we do not use the shorter n-alkanes because according LAREDO et al. (1991) these shorter n-alkanes having lower concentrations are able to increase the errors in the extraction procedure affecting the regression analyses. In addition, these n-alkanes are the most used in intake estimates studies.

The comparison between syringe and column extracts was performed with linear regression between values obtained with columns and syringes, using the Model Evaluation System (MES; TEDESCHI, 2006; http://nutritionmodels.tamu.edu).
We tested whether the intercept and slope were equal to zero and one, respectively, to verify if the methods were similar. The analyses of deviations (syringe minus columns values) were plotted against syringe values to verify the percentage of points lying within an acceptable range (95\%). Data points outside the range -2 to 2 of the studentized residue (regression predicted minus columns values) were considered outliers (influential points) and removed from the regression analysis. The mean bias (mean of the difference between columns and syringe values) associated with the technique was tested using Student-t test assuming paired values. The mean square error of prediction (MSEP) consists of the difference between columns and syringe values and it was used to estimate the accuracy via the root of MSEP (RMSEP).

$\mathrm{N}$-alkanes with length chain between 27 and 36 carbons were detected (data not shown), excepting the $\mathrm{C}_{34}$ used as internal marker, with the amount changing between 2 and $179 \mathrm{mg} \mathrm{kg}^{-1}$ of dry matter (DM) for concentrate and feces, respectively. The n-alkanes $\mathrm{C}_{31}$ and $\mathrm{C}_{33}$ were found in higher concentration on the feeds and orts (ranging from 2 to $45 \mathrm{mg} \mathrm{kg}^{-1}$ of dry matter for $\mathrm{C}_{27}$ and $\mathrm{C}_{36}$, respectively). On the fecal samples the $\mathrm{C}_{32}, \mathrm{C}_{36}$ and $\mathrm{C}_{33}$ were the most abundant (ranging from 9 to $179 \mathrm{mg} \mathrm{kg}^{-1}$ of dry matter for $\mathrm{C}_{35}$ and $\mathrm{C}_{32}$, respectively).

For feces, the regression of syringe on plastic column extracts had an $\mathrm{r}^{2}$ of 0.94 and the square root of the mean square error (RMSE) was $13.7 \mathrm{mg} \mathrm{kg}^{-1}$ $\mathrm{DM}(\mathrm{n}=30)$. No outliers were detected and, the intercept $(2.63 \pm 4.71)$ and the slope $(0.92 \pm 0.047)$ did not simultaneously differ from zero and unity $(\mathrm{P}>0.05)$, respectively, suggesting a good agreement between these two techniques in measuring n-alkanes from feces.

The syringe value was on average $4.5 \mathrm{mg}$ $\mathrm{kg}^{-1} \mathrm{DM}$ greater than column, but it was not different from zero $(\mathrm{P}>0.05)$. The square root of the mean square error of prediction (RMSEP) was $14.6 \mathrm{mg} \mathrm{kg}^{-1} \mathrm{DM}$, very close to the RMSE value. Random errors accounted for $81 \%$ of the MSEP (mean square error of prediction). The result for feces indicated that extractions of nalkanes either using syringe or plastic column for feces had similar values and both methods were equivalent.

For feeds, the regression of syringe on plastic column extracts had an $\mathrm{r}^{2}$ of 0.85 and RMSE of $1.86 \mathrm{mg} \mathrm{kg}^{-1} \mathrm{DM}(\mathrm{n}=21)$. Six outliers were detected based on leverage and Cook's distance analysis. Despite the low precision, the intercept and the slope did not simultaneously differ from zero and unity $(\mathrm{P}>0.05)$, respectively, suggesting a good agreement between 
these two techniques in measuring n-alkanes from feeds. Even though the least-square regression indicated that the intercept $(0.359 \pm 0.54)$ was not different from zero $(\mathrm{P}>0.05)$ and the slope $(1.12 \pm 0.11)$ was not different from unity $(\mathrm{P}>0.05)$.

Despite the low precision, there was little mean bias $\left(0.75 \mathrm{mg} \mathrm{kg}^{-1} \mathrm{DM}\right)$ between syringe and plastic column extractions $(\mathrm{P}>0.05)$. The RMSEP was $1.98 \mathrm{mg}$ $\mathrm{kg}^{-1} \mathrm{DM}$ and random errors accounted for $80 \%$ of the MSPE whereas mean bias accounted for $14.5 \%$ of the MSEP. The result for feeds indicated that extractions of n-alkanes using syringe and plastic column for feeds might not be as accurate and precise as the extraction for feces.

For orts, the regression of syringe $(\mathrm{X})$ on plastic column extracts $(\mathrm{Y})(\mathrm{Y}=0.49+0.92 \times \mathrm{X})$ had $\mathrm{an}^{2}$ of 0.98 and RMSE of $1.21 \mathrm{mg} \mathrm{kg}^{-1} \mathrm{DM}(\mathrm{n}=15)$. There were five outliers based on leverage and Cook's D analyses. The intercept and the slope did not simultaneously differ from zero and unity $(\mathrm{P}>0.10)$, respectively, suggesting a good agreement between these two techniques in measuring n-alkanes from orts (Figure 1).

There was nearly no mean bias $\left(0.09 \mathrm{mg} \mathrm{kg}^{-1}\right.$ $\mathrm{DM})$ between syringe and plastic column extracts (P>0.05). The RMSEP was $1.35 \mathrm{mg} \mathrm{kg}^{-1} \mathrm{DM}$, but only $70 \%$ of the MSPE was explained by random errors; the other $30 \%$ was accounted for systematic bias. The result for orts indicated that extractions of n-alkanes either using syringe or plastic column for feces concord.
Despite the good concordance, medium-tohigh precision and high accuracy of the comparison between these two techniques (syringe vs. column) in predicting n-alkanes concentration in feces, feeds, and orts, these techniques were not uniform. Most of the errors in the MSEP were random, but for feeds mean bias accounted for $14.5 \%$ whereas for orts systematic bias accounted for $30 \%$. This suggests the errors do not have the same pattern among these substrates/ residues which might be justified by the difference in n-alkanes concentration. Furthermore, the histogram of extracts (not showed) using either syringe or plastic column skewed to the right, meaning that most of the points were located in the lower quadrant of the scatter plot, few high-value data points were available, reflecting the lower concentration of the n-alkanes mainly in feeds and orts.

The results from this experiment shown that when the n-alkanes concentration was higher as in feces, the linear regression between methods and the measured analysis used were better than on the material with less concentration. The influence of concentration of n-alkanes on the accuracy of the analysis was studied by BROSH et al. (2003) measuring the regression of coefficient of variation (CV) on the n-alkane concentration. The authors showed the accuracy of nalkane analysis increased with increasing n-alkane concentration. Also, it has been pointed out by LAREDO et al. (1991) and DOVE \& MAYES (1991) that it might be possible increase the analytical error in diets when lower concentrations are observed.

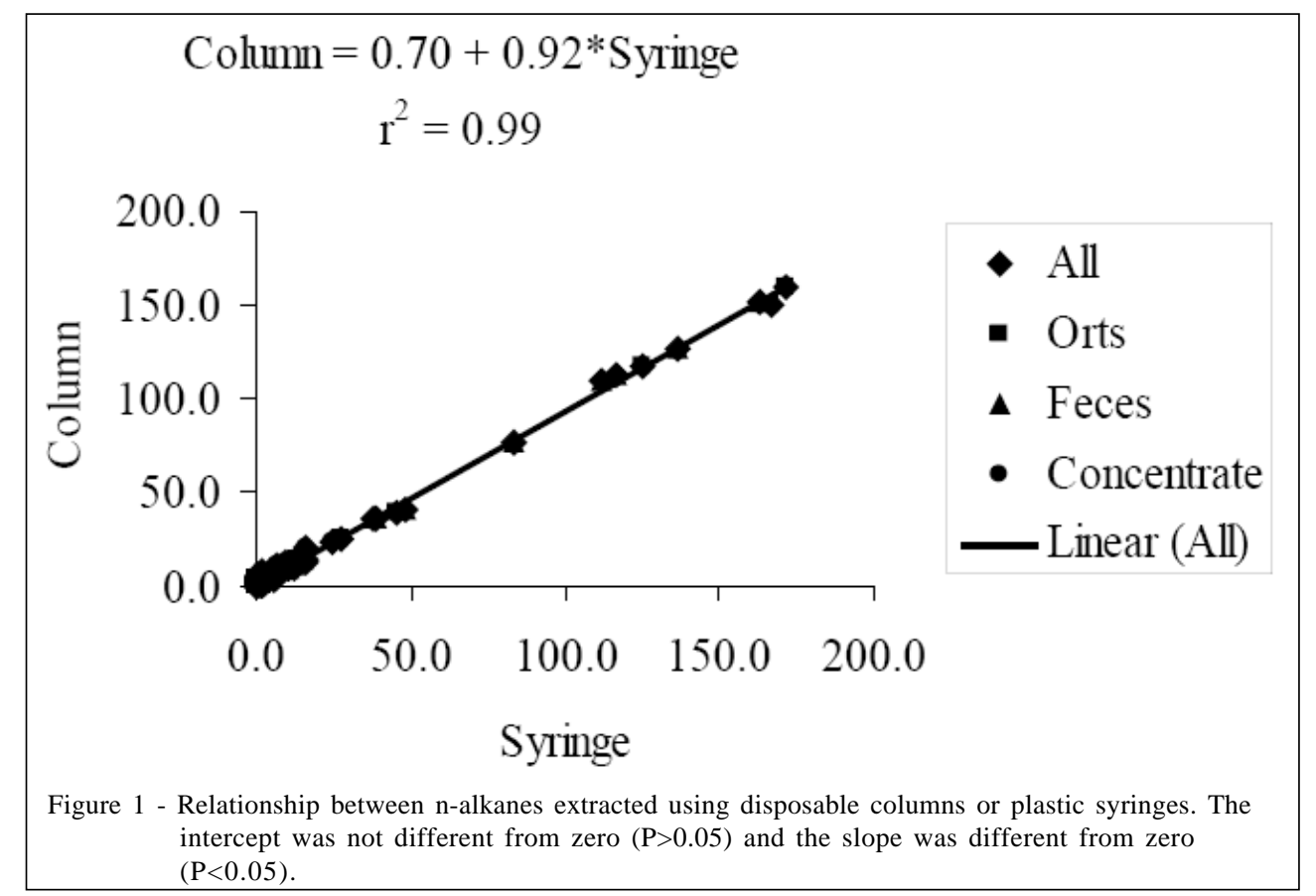

Ciência Rural, v.40, n.8, ago, 2010. 
Results obtained in this experiment were satisfactory as depicted by the low concentrations of $\mathrm{n}$-alkanes in feeds used and indicate that syringes could satisfactorily replace columns during the nalkanes extraction process.

Taking into account the associated analytical costs (syringes are less expensive than columns), syringes are a feasible alternative to columns in determining $n$-alkanes concentration. On the other hand, the advantage for columns is the reservoir that can be fitted on the top of the column to allow for more flexibility during the extraction process. However, because syringes did not influence the outcome of the analysis and have a significantly lower cost, they could be used as replacement to columns.

The result indicated that extractions of nalkanes using syringe and plastic column for feeds or orts might not be as accurate and precise as the extraction for feces when low concentration of $n$ alkanes are found affecting the values of both methods. Disposable plastic syringes are a viable alternative to imported columns and could be used in order to reduce analytical costs.

\section{REFERENCES}

BROSH, A. et al. Effects of faecal n-alkanes recovery in estimates of diet composition. Journal of Agricultural Science, v.140, p.93-100, 2003. Available from: <http:// journals.cambridge.org/action/displayIssue?decade $=2000 \& \mathrm{ji}$ $\mathrm{d}=$ AGS\&volumeId=140\&issueId=01\&iid $=148494>$. Accessed: Jul. 01, 2010. doi:10.1017/S0021859602002757.

DILLON, P.; STAKELUM, G. The analysis of n-alkanes in faeces and herbage. In: EUR GRAZING WORKSHOP, 7. 1990, Wageningen. Proceedings... Wageningen: Institut voor Veevoedingsoderzoek, 1990. Paper M8.

DOVE, H.; MAYES, R.W. The use of plant wax alkanes as marker substances in studies of the nutrition of herbivores: review. Australian Journal of Agricultural Research, v.42, p.913-952, 1991. Available from: <http://www.publish.csiro.au/ nid/43/issue/1095.htm>. Accessed: Jul. 01, 2010. doi:10.1071/ AR9910913.
LAREDO, M.A. et al. The potential for using n-alkanes in tropical forages as a marker for determination of dry matter by grazing ruminants. Journal of Agricultural Science, v.117, p.355-361, 1991. Available from: <http://journals.cambridge.org/ action/displayIssue?decade=1990\&jid=AGS\&volumeId=117 \&issueId=03\&iid=5179400>. Accessed: Jul. 01, 2010. doi:10.1017/S0021859600067101.

OLIVÁN, M.; OSORO, K. Effect of temperature on alkane extraction from faeces and herbage. Journal of Agricultural Science, v.132, p.305-312, 1999. Available from: http:// journals.cambridge.org/action/displayIssue?decade=1990\&jid= AGS\&volumeId=132\&issueId=03\&iid=7282. Accessed: Jul. 01, 2010. doi:10.1017/S0021859699006358.

OLIVEIRA, D.E. Determinação de alcanos: manual de extração e análise cromatográfica em forragens, concentrados e fezes. Piracicaba: FEALQ, 2004. 30p.

OLIVEIRA, D.E. et al. Identification and quantification of nalkanes in waxes of forage plants. Brazilian Journal of Animal Science, v.26, n.05, p.881-886, 1997. Available from: <http:/ / w w w.revistas bz.org.br/scripts/revista/sbz 1 / Resumo.asp?NumArtigo=126>. Accessed: Jul. 01, 2010.

OLIVEIRA, D.E. et al. N-alkanes to estimate voluntary forage intake of cattle uing controlled-release capsules. Scientia Agricola, v.65, n.3, p.230-238, 2008. Available from: <http:/ /www.scielo.br/pdf/sa/v65n3/a02v65n3.pdf. Accessed: Jul. 01, 2010. doi: 10.1590/S0103-90162008000300002>.

TEDESCHI, L.O. Assessment of adequacy of mathematical models. Agricultural Systems, v.89, p.225-247, 2006. Available from: < h t t p : / / w w w . s c i e n c e d i r e c t. c o m / science? ob=PublicationURL\& tockey $=\% 23$ TOC $\% 234957 \% 232$ 006\%23999109997\%23619842\%23FLA\%23\&_cdi=4957\&_pub Type $=J \& \_a u t h=y \& \_a c c t=C 000050221 \&$ \& version $=1$ \&_urlVersion $=0 \&$ _userid $=10 \& \mathrm{md} 5=\mathrm{f} 457 \mathrm{c} 5 \mathrm{aa} 65 \mathrm{a} 09 \mathrm{e} 627252732775 \mathrm{e} 1 \mathrm{f} 9 \mathrm{ba}>$. Accessed: Jul. 01, 2010. doi:10.1016/j.agsy.2005.11.004.

VULICH, S.A. A note on the use of alternative saponification procedures for the determination of n-alkanes in faeces. Irish Journal of Agricultural and Food Research, v.33, p.7173, 1994. Available from: <http://www.jstor.org/pss/ 25562219>. Accessed: Jul. 01, 2010.

VULICH, S.A. et al. Modification of the analytical procedures for the determination of herbage and faecal n-alkanes used in the estimation of herbage intake. Journal of Agricultural Science, v.124, p.71-77, 1995. Available from: http:// journals.cambridge.org/action/displayIssue?decade=1990\&jid=A GS\&volumeId=124\&issueId=01\&iid=4792088. Accessed: Jul 01, 2010. doi:10.1017/S0021859600071264. 